УДК 63.632,7

https://doi.org/10.32634/0869-8155-2021-350-6-62-64

Краткий обзор/Brief review

Торениязов Е.Ш.,

Бауетдинов Б.У.

Нукусский филиал Таш ГАУ, Узбекистан, Каракалпакстан, г. Нукус Х. Абдамбетова б/H. bbauetdinov@mail.ru

Ключевые слова: биотоп, биоценоз, сосущие вредителей, тли, трипс биологический метод, эффективность

Для цитирования: Торениязов Е.Ш., Бауетдинов Б.У. Особенности применения методов защиты озимой пшеницы в экстремальных условиях республики каракалпакстан. Аграрная наука. 2021; 350 (6): $62-64$.

https://doi.org/10.32634/0869-8155-2021-350-6-62-64 Конфликт интересов отсутствует

Elmurat Sh. Toreniyazov., Bakhtiyar U. Bauetdinov

Nukus branch of Tash GAU. Uzbekistan, Karakalpakstan Nukus H. Abdambetova w/o bbauetdinov@mail.ru

Key words: biotope, biocenosis, sucking pests, aphids, thrips biological method, efficiency

For citation: Toreniyazov E.Sh., Bauetdinov B.U. Features of application of methods for protecting winter wheat in extreme conditions of the republic of Karakalpakstan. Agrarian Science. 2021; 350 (6): 62-64. (In Russ.)

https://doi.org/10.32634/0869-8155-2021-350-6-52-60

There is no conflict of interests
Особенности применения

методов защиты озимой

пшеницы в экстремальных

условиях Республики

Каракалпакстан

PEЗЮME

В статье приведены результаты исследовании по изучению особенности возделывания пшеницы в экстремальных условиях Каракалпакстана. Изучены видовой состав вредных насекомых, обитающих в биоценозе пшеницы, особенности применения размноженных на биолабораторий златоглазки против пшеничной тли и условия их размножения в последующие периоды, с увеличением природных популяций на посевах пшеницы.

\section{Features of application of methods for protecting winter wheat in extreme conditions of the republic of Karakalpakstan}

\section{ABSTRACT}

The article presents the results of a study on the study of the peculiarities of wheat cultivation in the extreme conditions of Karakalpakstan. The species composition of harmful insects inhabiting the wheat biocenosis has been studied. features of the use of lacewings multiplied at the biological laboratory against wheat aphids and the conditions of their reproduction in subsequent periods, with an increase in natural populations on wheat crops 
Территория Республики Каракалпакстан расположена между 59o-76о восточной долготы и 36o-44o ceверной широты, в зоне пустынь умеренного пояса северо-западной части Республики Узбекистан. Важным фактором для развития земледелия, особенно возделывание сельскохозяйственных культур, является характерное значение агроклиматического условия региона. В агробиоценозе страны размещены скороспелые сортахлопчатника, пшеницы, риса, плодовых, кормовых и овощебахчевых культур. Широкомасштабное выращивание различных сортов озимой пшеницы практикуется только в последнее десятилетие и в настоящие время площади занимаемые культурой составляет более 55 тысяч гектаров. Основные площади размещены на посевах фермерских хозяйств и частично на приусадебных участках. [1]

Возделывание сортов пшеницы имеет характерные признаки выращивания. Оптимальным сроком посева озимой пшеницы в экстремальных условиях Каракалпакстана является период с 10 сентября по 10 октября. Поэтому посев проводился до 10 октября, которые в оптимальном сроке накапливается в надземных органах прорастающих растений. Такие растения нормально зимуют и с весны продолжают рост и развитие. Весной при повышенной температуре воздуха от $+2^{\circ} \mathrm{C}$ продолжается рост и развитие и до конца весны созревает зерна, которые собираются в течение июня $[1,3,6]$.

Основной целью задачи исследования является определение видового состава вредителей, обитающих на посевах озимой пшеницы, биоэкологической особенности развития, вредоносности. В основе этих результатов приведены защитные мероприятия для сохранения урожая от доминантных видов вредителей пшеницы. [9]

\section{Методы исследования}

При определении видов энтомофагов и вредителей распространенных в биотопе пшеницы, выращиваемые в условиях Каракалпакстана, применялись методы Б.П. Адашкевича, Ш.Т. Хужаева и при определении вредоносности вредителей применялись методы И.В. Танского. Результаты исследовании анализировались дисперсионным методом, применяя математическо-статистический метод Б.А. Доспехова. [2.4.5.8]

\section{Результаты}

В результате проведенных исследований установлено, что с фазой всходов, кущения и образования листьев осенью на биотопе создаются благоприятные условия для накопления многих видов насекомых, с помощью которых они уходят на зимовку с успешным перезимованием в данных условиях. Весной при повышенной температуре воздуха, перезимовавшие особи вредителей с началом прорастания пшениц активно продолжают размножение и в коротком периоде наносят огромный вред культурам.

Как следствие этого, можно отметить, что накапливающиеся особи вредителей такие как озимая совка (Agrotis segetum Den. Et), восклицательная совка (Agrotis exclmationi L.), клоп (Lygus pratensis L.), урюково-камышевой тли (Hyalopterus pruni F.) на посевах осенью и в течение вегетационного периода наносят незначительный вред культурам. [2]

По ареалу распространения и нанесенным вредом культуре доминантными оказались специфические виды вредителей такие как пшеничный трипс (Haplothrips tritici Kurd), пшенишные тли (Schizaphis graminum Rond), вредная черепашка (Eurygaster integriceps Put), пьявица (Lema melonopus L.), против которых ежегодно проводится комплекс методов защиты растений. $[3,10]$

Из-за непосредственного воздействия этих вредителей, несмотря на проведение защитных мероприятии, ежегодные потери урожая пшеницы составляют $25-40 \%$, с резким ухудшением качества полученной продукции.

Поэтому для усовершенствования применяемых методов, в настоящее время в данном регионе изучается развитие биоэкологии, динамика численности и вредоносности этих видов вредителей, а также их энтомофаги в зависимости от абиотических и биотических факторов биоценоза.

Установлено, что перезимовавшие особи вредителей пшеницы впервые обитают с третьей декады апреля и динамика развития продолжается до конца мая, в отдельные годы до первой декады июня. Количество пшеничного трипса увеличивается от 3,2-10,6 экз. на растении с началом выхода из мест перезимовки до 127,4-165,2 экз. к концу вегетации, а также увеличиваются пшеничные тли с 2,1-7,5 экз. на 100 растений до 143,1-216,7 экз. Темп развития вредной черапашки оказался более характерным. На полях пшеницы зафиксированы в количестве 1,4-3,0 экз. на 100 растений. Их численность увеличивалась до 19,2-35,6 экз. в конце мая и наносили серьезный вред культурам.

Пшеничный трипс, обитаемый в количестве до 27,3 экз. на 1 кусте, снижает объем урожая на 0,21 г, если пшеничные тли обитают в количество 9,6 экз. в каждом растении, в конце вегетаций снижает на 10,1 ц урожая с каждого гектара.

Более вредоносными оказались обитание вредной черепашки, которые размножались с 1 до 10 экз. на $10 \mathrm{M}^{2}$, что приведет к снижению 307,9 шт. колос на $1 \mathrm{M}^{2}$, что приводит к потери 7,9 центнера урожая с каждого гектара.

В вышеотмеченном видно, что в условиях данного региона, в связи с отсутствием оптимальных защитных мероприятий против вредителей, урожайность и качество пшеницы снижаются. Поэтому целесообразно проведение защитных мероприятий против вредоносных видов вредителей пшеницы, учитывая особенности влияния абиотических и биотических факторов.

Применение элементов, интегрированной системы защиты пшеницы, в основе биологического метода против вышеотмеченных видов вредителей, является перспективным методом. Практика подтверждает, что создание благоприятных условий для массового развития энтомофагов и их своевременный выпуск способствует уничтожению доминирующих видов вредителей. Со временем численность энтомофагов постепенно увеличивается и в течение вегетационного периода они активно регулируют количество вредителей на пороге ниже вредоносности.

Для изучения эффективности применения в биолаборатории размножались особи хищника-златоглазка при помощи искусственного выпуска против пшеничной тли, появляющейся с ранней весной. В результате проведенного испытания получен положительный результат. Выпуск осуществлялся в расчете 500-3000 экз. на гектар с третей декады апреля и в течение вегетационного периода определена биологическая эффективность энтомофага. [8]

Установлено, что выпуск златоглазки в фазе имаго, яиц и личинки в расчете 500-3000 экз. на гектар снижает численность тли и увеличивает биологическую эф- 
Фективность полей на 62,6-70,3\% в течение 20-30 дней после выпуска по сравнению с полями, где отсутствовал выпуск энтомофага. На полях пшеницы златоглазки стимулируют увеличение численности естественной популяции энтомофага в течение вегетационного периода. На посевах пшеницы, выпущенные златоглазки до сбора урожая достигли 18,6-27,2 экз. на 100 растений. В последующие периоды размноженные особи на посевах пшеницы массово мигрировали на другие поля и до конца вегетационного периода активно снижали численность вредителей. [5, 8]

\section{Выводы}

Таким образом, на посевах пшеницы в экстремальных условиях Республики Каракалпакстан активно обитают много видов вредителей сельскохозяйственных культур, из которых по ареалу распространения и объема нанесенным вредом доминантными оказались

\section{ЛИТЕРАТУРА}

1. Исмайлов У.Е. Дийханшылық илим изертлеў тийкарлары менен, Сабақлық, - Нөкис, «Билим». 2015. 256 б. [Ismaylov U.E. With the basics of agricultural research, Textbook, Nukus, Bilim. 2015. 256 p. (In kk)]

2. Доспехов Б.А. Методика полевого опыта. - М.: Колос, 1985. -351 c. [Dospekhov B.A. Field experiment technique. - M Kolos, 1985.-351 p (In Russ)].

3. Торениязов Е.Ш. Хўжаев Ш.Т., Холмуратов Э.А. Ўсимликларни химоя килиш -Тошкент: «Navroz», 2018. -876 c. [Toreniyazov E.Sh. Khojaev Sh.T., Kholmuratov E.A. Plant protection - Tashkent: "Navruz", 2018. - 876 p. (In uzb)].

4. Танский В.И. Биологические основы вредоносности насекомых. М: «Агропромиздат»; - 1988: 89-150 с. [Tansky V.I. Biological bases of harmfulness of insects. -Moscow, Agropromizdat; 1988: 89-150 p. (In Russ)]

5. Хужжаев Ш.Т. в.б. Инсектицид, акарицид, биологик фаол моддалар ва фунгицидларни синаш буйича услубий кўрсатмалар. Il-нашр. -Тошкент, «Navroz; 2004: 4-13 б. [Khojaev Sh.T. v.b. Guidelines for testing insecticides, acaricides, biologically active substances and fungicides. II edition. -Tashkent, "Navruz"; 2004: $4-13 p$. (In uzb)]. пшеничные тли, пшеничный трипс и вредная черапашка. Для снижения численности этих видов вредителей с ранней весной при появлении перезимовавших особей пшеничных тли необходимо выпускать размноженные в условиях биолаборатории златоглазки в расчете 500-3000 экз. на гектар. При этом, своевременное уничтожение вредоносных видов тли на 62,6-70,3\% способствует увеличению численности естественной популяции энтомофагов на 18,6-27,2 экз. на 100 растений.

При проведений защитных мероприятии с использованием $10 \%$ к.э. киллер экстра - 0,1 л/га, 5\% к.э. эсфен-алфа - 0,3 л/га, 55\% к.э. циперфос-0,5 л/га, против пшеничного трипса, пшеничной тли и вредной черепашки биологическая эффективность составляет $97,1-98,9 \%$ \% с сохранением 9,0-14,7 ц/га урожая. В результате экономическая эффективность защиты составляет 1678,0 сум/га.

6. Торениязов, Е.Ш., Юсупов Р.О., Ешмуратов Э.Г. Развитие вредителей на посевах овощебахчевых культур. Аграрная наука. 2014; (6): 15-16. [Toreniyazov, E.Sh., Yusupov R.O., Eshmuratov E.G. The development of pests on crops of vegetable and melon crops. Agricultural science. 2014; (6): 15-16(In Russ)]

7. Шамуратова Н.Г. Вредоносность люцерновой тли на люцерне в Каракалпакстане. Аграрная наука. 2004; (11): 1416. [Shamuratova N.G. Harmfulness of alfalfa aphid on alfalfa in Karakalpakstan. Agricultural science. 2004; (11): 14-16 (In Russ)]

8. Адашкевич Б.П. Златоглазка: за и против. Защита растений. 1987; (7): 29-30. [Adashkevich B.P. Lacewing: pros and cons. Plant protection. 1987; (7): 29-30 (In Russ)].

9. Уразбоев А.А. Ғаллани зараркунандалардан химоя қилиш. Ўзбекистон қишлоқ хўжалиги журнали. 2010; (12): 11-13. [Urazboev A.A. Protect grain from pests. Journal of Agriculture of Uzbekistan. 2010; (12): 11-13 (In uzb)]

10. Уразбоев А.А., Хужаев Ш.Т. Ғуза қатор орасида ғалла етиштиришнинг зараркунандалар ривожланишига таъсири. Ўсимликлар химояси ва карантини. 2016; (2): 25-26. [Urazboev A.A., Xujaev Sh.T. The effect of grain cultivation on cotton development among pests. Plant protection and quarantine. 2016; (2): 25-26 (In uzb)].

\section{НОВОСТИ•НОВОСТИ•НОВОСТИ•НОВОСТИ•}

\section{Оливки посчитали, оценили и оцифровали}

Ученые Крымского федерального университета создали цифровой двойник единственной в Российской Федерации оливковой рощи, высаженной в защищенном грунте. Цифровая карта позволит наблюдать за развитием каждого отдельного дерева и рощи в целом, сообщает Агро.ru, со ссылкой на пресс-службу вуза.

Для каждого дерева в базу данных вносятся: идентификационный номер, ряд, GPS-координаты, сорт, время высадки, диаметр, высота дерева, количество придаточных ветвей, общее состояние. Затем создаются сортополосы и контрольные полосы. В них тестируются различные препараты, стимулирующие рост растений и влияющие на их стрессоустойчивость. Оцифровка позволит подобрать самые эффективные технологии для развития оливок. Кроме того, специалисты добавят в базу данных фотографии, чтобы визуально оценивать прирост и общее состояние растений. Таким образом аграрии смогут наблюдать за всеми изменениями и темпами развития деревьев.
Площадь теплицы составляет 0,75 га, она рассчитана на 2000 посадочных мест. На данный момент в теплице высажено 350 саженцев оливы четырех сортов. К концу года их количество планируют увеличить до 1700.

В основном планируется использовать сорта собственной селекции, а также иностранные сорта, такие как Leccio del Corno, Pendolino, Arbequina, Leccino, Maurino, Bianchera, а также оливу европейскую. Ее возраст составляет порядка 500 лет, поэтому выделить сорт этого дерева не представляется возможным.

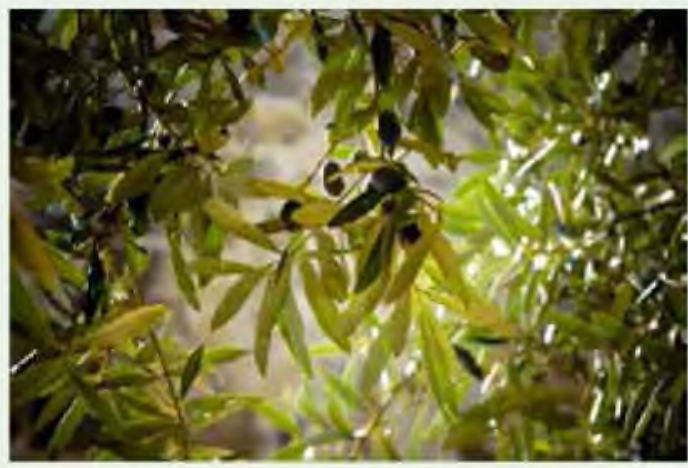

